\title{
Migration or Expulsion of Device
}

National Cancer Institute

\section{Source}

National Cancer Institute. Migration or Expulsion of Device. NCI Thesaurus. Code C62917.

Problem with an implanted or invasive device moving within the body, or being completely expelled from the body. 